\title{
Housing renewal policies, house prices and urban competitiveness
}

\author{
Xin $\operatorname{Liu}^{\mathrm{a}, \mathrm{b}, *}$ \\ a Yantai Institute of Coastal Research for Sustainable Development, Chinese Academy of Sciences, Yantai 264003, China \\ ${ }^{\mathrm{b}}$ The University of Birmingham, B15 2TT, Birmingham, UK
}

Keywords:

Urban competitiveness

Housing price

Housing market renewal policies

Temporal-spatial analysis

\begin{abstract}
A B S T R A C T
There has been a growing emphasis in housing policy and its impacts on sub-regional economies. Yet the arguments linking housing and economic competitiveness are typically described in very general terms. First of all, this paper is based on research providing a spatial picture of house prices utilising housing data from the UK government's Land Registry and presenting key findings from analysis of 1996-2006 house price trends at three spatial scales: within the policy area (Transform South Yorkshire (TSY) Pathfinder, within the South Yorkshire sub-region (SY) and within the wider region of Yorkshire and the Humber $(\mathrm{YH})$ ). Secondly, a quantitative analysis is applied in this paper to examine the relationship between economic competitiveness and housing in four sub-regional local authority districts (LADs) of South Yorkshire, UK. It demonstrates that housing prices in local authority districts affect some form of economic competitiveness. Overall, although evidences suggest that the UK government's housing market renewal program has resulted in some success in reinvigorating the local housing market, the objective of reducing or eradicating spatial differentiation in house prices will require a long-term commitment and a radical reappraisal of sustainable housing and planning policy.
\end{abstract}

(C) 2009 Elsevier Ltd. All rights reserved.

\section{Introduction}

From the mid-1970s onwards, the UK economy has been significantly restructured (Pemberton, 2002). A number of core themes are prominent in these changes including a shift from primary and manufacturing industries to service sector employment (Green, 2003). As a consequence, there were large-scale job losses in manufacturing and primary industries such as coal mining in northern England. Whilst the economic impacts were easily identifiable, the social impacts of restructuring took much longer to play out and the housing market responses to economic restructuring of the 1970s, began only to emerge in the mid-1990s in the UK (Lee \& Ferrari, 2006). Parts of the north and midlands suffered on a large scale from the extreme problems of dereliction and abandonment of properties, declining waiting lists for social housing. In the literature, there was extensive debates and described it as low and changing demanding for housing (Mullins, 2006; Murie, Hall, Rowlands, \& Sankey, 2005). To intervene the existing trends towards low and changing demand, the government response was the introduction of Housing Market Renewal Pathfinders (HMRP) (Jones \& Murie, 2006; Mullins, 2006). Together with a number of economic diversification and economic regeneration plans aiming for delivering urban renaissance, Housing Market Renewal Pathfinders (HMRP) was designed to deliver a better fit between economic and housing aspirations through attracting and retaining households to areas now in high level of deprivation and rates of economic inactivity affected by past economic decline. The policy had more direct objectives including the reduction of low demand (abandoned properties) and reducing the gap in house prices within the region (Liu \& Lee, 2008).

\footnotetext{
* Yantai Institute of Coastal Research for Sustainable Development, Chinese Academy of Sciences, Chunhui Road 17, Yantai 264003, China. Tel.:+86 535 2109193.

E-mail address: xliu@yic.ac.cn
} 
Within the progress of globalization, the importance of the concept of competitiveness has increased rapidly in recent years. According to Porter (1990) and Thurow (1993), national competitiveness was defined as an outcome of a nation's ability to innovate in order to obtain a world-class standard of living for its citizens in a number of knowledge-based industries. City region competitiveness can be conceptualized and measured in terms of a range of indictors including economic diversity, skilled workforce, innovation in firms and organizations, and living quality (Deas, 2001; Kresl, 1995; Rogerson, 1999). In this respect, we consider the most appropriate definition of competitiveness to be that developed by the American economist Michael Storper. He took competitiveness as the capability of an economy to attract and maintain firms with stable or rising markets shares in an activity, which maintains stable or increasing standards of living for those participating in it (Huggins \& Day, 2006; Scott \& Storper, 2003; Storper, 1996). Based on this definition, the UK competitiveness first introduced and published in April 2000, has been devised and compiled by Robert Huggins to be an integrated measure of headline economic performance, the knowledge economy, the enterprise economy, education and the skills economy. The UK competitiveness index was designed to reflect the 3-factor model, which consists of a framework of competitiveness based on: (1) inputs; (2) outputs; and (3) outcomes (Huggins, 2003). The key inputs factors include business density, proportion of knowledge-based business and economic activity rates. These inputs factors contribute to the output-productivity of an area, measured by GDP per capita (Huggins, 2003). Finally, full time wages and unemployment rates are used as tangible outcomes to measure the impact of those factors. More details can be found in Huggins (2003). The 2006 edition of the UK competitiveness index used in this paper represents the most up-to-date, thorough and authoritative benchmarking of the competitiveness of the UK's region and localities.

Housing constitutes a large share of the overall economy (Shinm, An, Cho, Kim, \& Kang, 2008). The significance of the housing market in economy has been illustrated in many research papers (Greenwood \& Hercowitz, 1991; Skinner, 1989). For example, detailed figures of the UK's wealth show that the most valuable asset in 2007 continues to be housing, with a total value of $£ 4,314$ billion. This is equivalent to $62 \%$ of the nation’s wealth (Office for National Statistics, 2008). It has become common to say that housing and economic competitiveness go together indeed to claim that housing actually adds value to economy ( $\mathrm{Ng}$, Skitmore, \& Wong, 2008). In view of Maliene and Malys (2009), housing is a key issue to be considered in delivering healthy and attractive communities. Moreover, housing might contribute to the development of a knowledgebased economy and to be the pivotal role of attracting and retaining the most talented and skilled members of the workforce that will be the catalysts of economic growth in the future (Parkinson, Simmie, Clark, \& Verdonk, 2004). To enhance the capabilities of region or locality to attract global capital, region reorganizes the exiting spatial structure and offer economic advantage to investors in the global market (Guezey, 2009; Hall \& Hubbard, 1998; Soe, 2009). However, knowledge detailed enough to connect the housing market and economic competitiveness is scarce. A literature review by Leung (2004) of macroeconomics and housing indicates that interactive nexus between and among housing market and urban economics is ignored virtually by conventional economics research. Generally, qualitative analyses are applied to examine the relationship between housing and urban economies. For instance, Soe (2009) suggested that providing quality housing for residents is one of major preconditions in the creation of competitive regional economies. The increased rent has been facilitated in Ankara, Turkey due to a rapid and complete renewal enhancing the competitiveness of the city (Guezey, 2009). One can also conceive of plausible counter-arguments and inverse relationships whereby real housing price rises above a certain threshold, business and households move to other city, which constrains competitiveness of city (Leung, 2004). An examination of previous studies on relationship between the housing market and the city suggests that much of housing market fluctuations may actually emanate from fluctuations in urban areas and the neighborhood effects may have important impacts upon household ownership behavior (see Chatterjee, 2003; Dobkins \& Ioannides, 2001; Glaeser, 2000; Glaeser \& Gyourko, 2001; Glaeser \& Scheinkman, 2003; Ioannides, 2003; Ioannides \& Overman, 2003; Ioannides \& Zabel, 2003; Rossi-Hansberg \& Wright, 2004). Therefore, an improved understanding of how these economic and social processes interact is an under-explored economic phenomenon for development strategies to achieve durable effects, with more emphasis on lasting solutions and less on palliatives. The paper focuses on both quantitative assessment of the effectiveness of Housing Market Renewal Pathfinders (HMRP) policy in the sub-region of South Yorkshire, UK and exploration of relationship between housing prices and economic competiveness provided in localities.

\section{Overall context of Transform South Yorkshire (TSY)}

The South Yorkshire (SY) consisting of four local authority districts: Sheffield, Barnsley, Doncaster and Rotherham as shown in Fig. 1, is one of four Yorkshire and the Humber $(\mathrm{YH})$ sub-regions. Within the sub-region, more than 40\% of the workforce are in Sheffield and the remaining boroughs of Rotherham, Barnsley and Doncaster have broadly equal working age populations (EKOS, 2006). There is very strong labor market linkage between the four areas. Some $15.4 \%$ of total South Yorkshire jobs involve a cross border commute between the four local authority districts. The three metropolitan boroughs of Barnsley, Doncaster and Rotherham provide more workers to the Sheffield economy than the reverse. At the end of 2004, business services and wholesale and retail trade, repairs accounting for 50\% of all business represent the two significant sectors in South Yorkshire (Annual Business Inquiry, 2004). Meanwhile, it was estimated that 20\% of the 50,000 additional employee jobs that could be created between 2001 and 2021 will result from employees moving into South Yorkshire (Transform South Yorkshire, 2005). Undoubtedly, this will include an increase of the number of employee in high added value sectors of the South Yorkshire economy, such as high technology and knowledge-intensive sectors. These employees will be generally more mobile and have significantly more choice in the housing market than existing local residents (Transform 


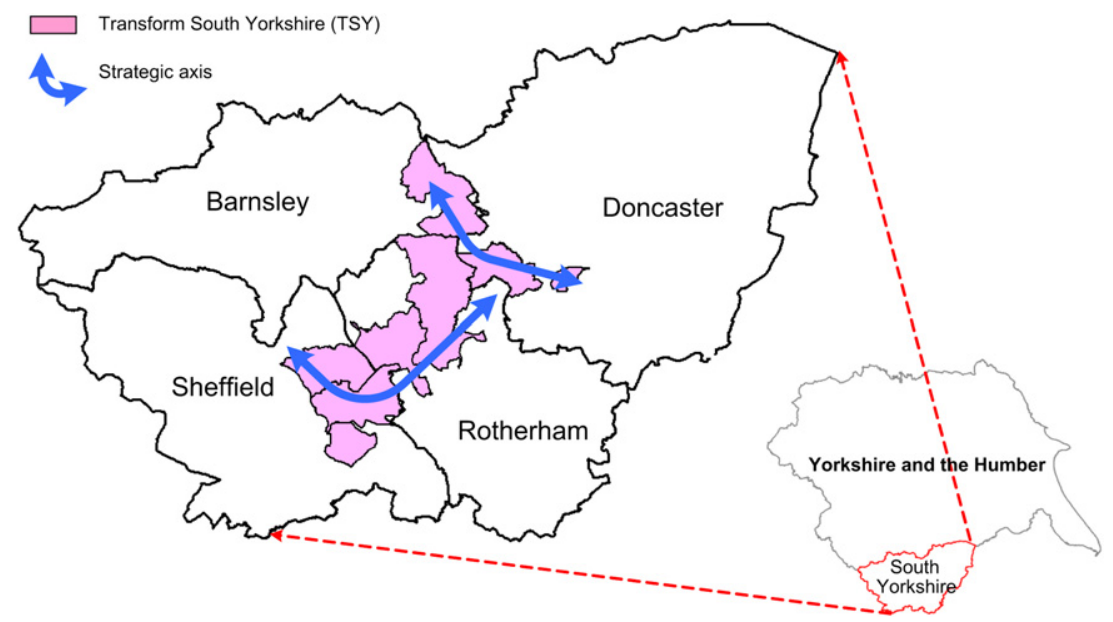

Fig. 1. Four local authorities in South Yorkshire and the twin strategic axes covering Transform South Yorkshire (TSY) Pathfinder areas.

South Yorkshire, 2005). There are over 130,000 dwellings in South Yorkshire (SY). More than half of dwellings are estimated to be at risk of experiencing low or changing demand in the parts of South Yorkshire. Without transformational change in the South Yorkshire housing market, this currently existing housing and neighborhood offer will do little to attract new, skilled population groups. Under such circumstances, Transform South Yorkshire (TSY) Pathfinder as the largest of the Housing Market Renewal Pathfinders (HMRP) has set up in 2003. The role of Transform South Yorkshire (TSY) is to tackle low and falling housing demand in South Yorkshire. When considering affordable housing, there is a significant gap in tenure structure between TSY area and the wider SY sub-region. Only $48.5 \%$ of residents in TSY are owner occupier while $65 \%$ on average in the South Yorkshire. On the other hand, up to 43\% rent their accommodations from the Council within TSY areas, whilst just 21.5\% within SY. During 1990s, housing completion within TSY pathfinder area is much lower, accounting for only $15 \%$ share of the South Yorkshire sub-region. The detailed program of TSY, starting from 2003 to 2018 includes radical and sustained actions to replace obsolete housing with modern sustainable accommodation, through demolition, refurbishment and new building. In the period of 5 years from 2003 to 2007, Transform South Yorkshire (TSY) has invested almost $£ 112$ million to acquire and demolish 2655 properties. In addition, 3788 properties have been refurbished and 178 newly built. The majority of the refurbished properties (90\%) have been in the private sector. Moreover, TSY program is expected to close the gap in vacancy rates between pathfinder areas and the region by 2010 and to close the gap in house prices between pathfinder areas and the region by one third by 2010. By 2018, TSY will aim to radically transform the quality and range of housing available and help create and support successful neighborhoods where people choose to live and from where it is hoped they play a full and active part in the economic and social renaissance of South Yorkshire.

\section{The data and methods}

This paper has a broad relevance to understanding housing market development, economic competitiveness and sustainability issues. The research uses a range of information sources and methods. Data used for analysis include housing transaction and price and economic competitiveness index. About 11 years housing transaction and price data from 1996 to 2006 for the whole region of Yorkshire and the Humber are got from the UK government's Land Registry. Competitiveness index for 2000, 2001, 2002, 2005 and 2006 covering metropolitan areas of South Yorkshire are from the work by Robert Huggins Associates (2002). Methods involved in this paper include temporal-spatial analysis with MAPINFO ${ }^{\mathrm{TM}}$ and statistical regression of variables. Temporal-spatial analysis provides a spatial picture of house prices and presents key findings from analysis of 1996-2006 house price trends at three spatial scales: within the policy area (TSY), within the South Yorkshire subregion (SY) and within the wider region of Yorkshire and the Humber (YH). From this, a quantitative assessment of the effectiveness of the policy within the Yorkshire and the Humber region is concluded. Additionally, a linear model was regressed based on five urban competitiveness index datasets to explore the relationship between economic competitiveness and housing prices in four sub-regional local authority districts (LADs) of South Yorkshire (SY).

\section{Results and discussions}

\section{Average house prices}

Transform South Yorkshire (TSY) Pathfinder set out two strategic axes covering seven sub-areas mainly located in South Yorkshire (see Fig. 1). These are the locations with the greatest need for intervention and the strongest opportunities for 
positive change. This point is totally consistent with the finding as shown in Fig. 2. Apparently, average house price of 2006 in the region of Yorkshire and the Humber $(\mathrm{YH})$ is in an inequity of distribution. Housing prices estimated by interpolation of IDW (Inverse Distance Weighting) embedded in MAPINFO ${ }^{\mathrm{TM}}$ are much higher in the northern part of the region, compared with those in the southern part highlighted with a solid circle. Namely, by comparing house prices in different local authority areas of the region of Yorkshire and Humber, it is suggested that house market in the South Yorkshire (SY) is less developed. Therefore, policy on housing market renewal concerning the Transform South Yorkshire (TSY) Pathfinder areas is expected to be reasonable to boost its local housing development.

Moreover, house prices in the TSY are below the average for SY and YH. This is to be expected considering the character of TSY Pathfinder areas and their staring point in 2003. Average house prices in the TSY Pathfinder areas increased from around $£ 30,000$ in 1996 to $£ 100,000$ in 2006 . This threefold increase is significant but when the data is analyzed in this way, it suggests that house price increases in TSY have been slower than either the sub-regional or regional average. Fig. 3 below shows year-on-year change of average house prices. It is estimated with adjusted CPI (Consumer Price Index, for reference see National Statistics, 2009) for housing as follows,

$$
\alpha_{t}=\frac{\left(A P_{t}-A P_{t-1}\right)^{*}}{A P_{t-1}} 100 \% ; \quad t=1997,1998, \ldots, 2006
$$

Where $\alpha_{t}$ denotes year on year change in percent for year $t$; $A P_{t}$ represents adjusted house price in year $t$. This analysis allows us to unpick the trend, which suggests that TSY is lagging behind sub-regional house price increase, and shows that house prices in the pathfinder areas have increased to a greater degree, year-on-year, than those in the wider region. This trend peaked in 2004. The house prices in TSY increase as early as 2002, a full year before the TSY program was implemented in 2003. Markets or other forces are likely to contribute to the initial "development". The increase in 2003 and 2004 can be explained by local knowledge of the government's plans and observed activities, further by the utility of TSY program, respectively. Early pathfinder funding was used for physical interventions including the demolition of poor quality, low demand properties in the period of 2003-2005. A shift in expenditure from physical intervention to non-physical intervention happened in 2005 and continued in 2006. Between 2005 and 2006, stock condition and visioning exercises as nonphysical interventions took place in order to develop the long-term plans for the estate, which possible resulted in a short term slow increase of TSY house price in both 2005 and 2006. Overall, the change of TSY house prices follows the sub-regional and national trend, which is attributed to the general UK housing market.

\section{Prices by property type}

After 2003, year-on-year house price change for all property types in TSY Pathfinder areas showed a greater increase than both YH and SY averages. This is illustrated by the highlighted number in Table 1. Even though house prices for detached properties were increasing at a less high rate, they nonetheless continued to increase. With regard to flats at the three spatial

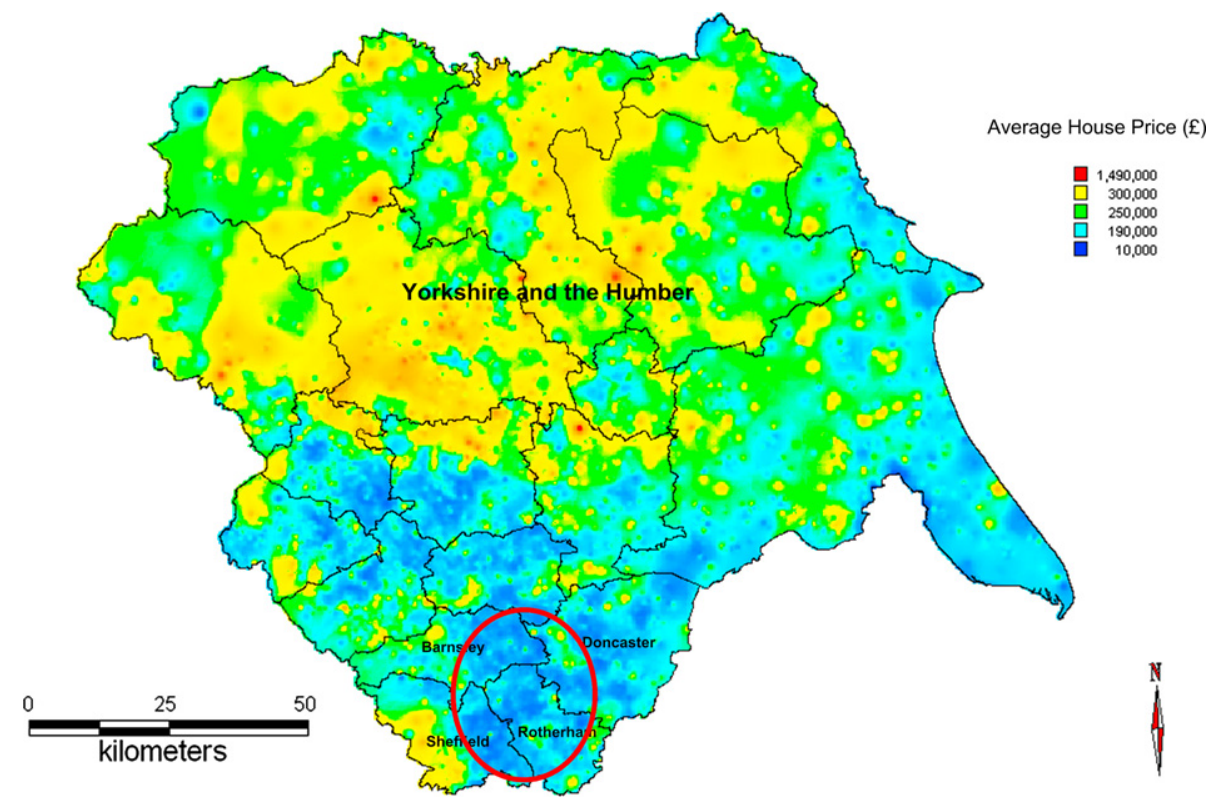

Fig. 2. House price distribution at year of 2006 is estimated for the whole region of Yorkshire and the Humber. Less developed housing markets in South Yorkshire is highlighted by red solid circle. 


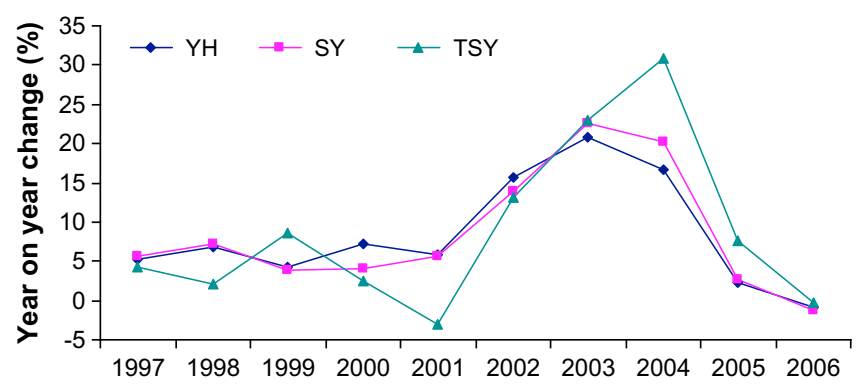

Fig. 3. Year-on-year change of average house price with adjusted Consumer Price Index for housing in UK. YH: Yorkshire and the Humber; SY: South Yorkshire; TSY: Transform South Yorkshire.

scales, Table 1 shows that after 2003 both flat and terraced house prices in TSY area increased to a much greater extent than the sub-regional and regional average. This can be explained by the fact that a majority of flats and terraced properties were regenerated in TSY Pathfinder areas during the period of 2003-2007. Since 2003, the year-on-year change of house price for the semi-detached properties in TSY increased over that of SY and YH. Amongst terraced properties, house prices have increased rapidly since 2003 in the TSY areas. For all types of properties in TSY, their year-on-year changes were peaked on 2004. This point was illustrated and highlighted in Table 1.

As seen in Fig. 4, analysis of year-on-year change of house prices since 1996 for different types of property in TSY Pathfinder areas shows us that that house price increases have been most significant amongst flats, with the greatest increases taking place after 2003. This is followed by terraced properties, then detached and semi-detached. As mentioned previously, it could be attributed to the major proportion of regeneration for flats and terraced properties in the short term since 2003 within Transform South Yorkshire (TSY) Pathfinder areas. One of the key themes of TSY program, a 15-year program by 2018, is to increase access and house options for residents. Therefore, the detached and semi-detached properties will be targeted during the forthcoming time period of the program.

\section{Competitiveness index}

Fig. 5 highlights the visualization of the UK urban competitiveness index for all wards in South Yorkshire in 2002, indicating that the sub-region as a whole lacks the economic competitiveness to compete at the national level. Totally, 8 of the top 20 ranked wards in South Yorkshire are within the boundaries of the Sheffield. The top ranked ward for the whole South Yorkshire is the ward of Netherthorpe in Sheffield, which boasts an urban competitiveness index score of 145.5. Barnsley has the second largest collection of wards (i.e. 5) within the top 20 followed by Rotherham with 4 and Doncaster with 3 wards (Robert Huggins Associates, 2002). Generally, this result of competitiveness does agree with average house price distribution mentioned previously. It brings on a question, if a fully developed housing environment implies a relative competitive urban economy?

Following the question arising, the relationship between UK urban competitiveness index for four local authority districts in South Yorkshire and their corresponding housing price gap compared with the region of Yorkshire and the Humber is examined by statistical regression. Only urban competitiveness index scores for 2000, 2001, 2002, 2005 and 2006 are available and collected in the local authority level, noted as a dependent variable IND. House price gap between the individual local authority district and the wider region of Yorkshire and the Humber was calculated for those years, respectively. Here

Table 1

Percent of year-on-year change (\%) adjusted with Consumer Price Index for different types of properties. YH: Yorkshire and the Humber; SY: South Yorkshire; TSY: Transform South Yorkshire.

\begin{tabular}{|c|c|c|c|c|c|c|c|c|c|c|c|c|}
\hline \multirow[t]{2}{*}{ Year } & \multicolumn{3}{|c|}{ Detached house } & \multicolumn{3}{|c|}{ Semi-detached } & \multicolumn{3}{|l|}{ Flat } & \multicolumn{3}{|c|}{ Terraced house } \\
\hline & YH & SY & TSY & $\mathrm{YH}$ & SY & TSY & YH & SY & TSY & YH & SY & TSY \\
\hline 1997 & 4.5 & 4.2 & 9.5 & 2.4 & 2.4 & 0.3 & 6.8 & 2.5 & 14.4 & 3.1 & 3.3 & 0.7 \\
\hline 1998 & 6.4 & 8.8 & 0.6 & 2.4 & 2.3 & -1.1 & 7.3 & 9.8 & 18.2 & 3.7 & 4.9 & 2.5 \\
\hline 1999 & 2.5 & 0.8 & 10.6 & 2.8 & 3.8 & 4.8 & 6.4 & 11.1 & -19.9 & 4.2 & 3.1 & 0.4 \\
\hline 2000 & 7.3 & 7.0 & 3.4 & 5.8 & 2.1 & 1.9 & 16.5 & 17.9 & -1.0 & 6.1 & 1.3 & 1.6 \\
\hline 2001 & 9.0 & 8.1 & 2.2 & 7.8 & 7.9 & 2.3 & 12.5 & 8.1 & 10.8 & 6.1 & 4.5 & 1.0 \\
\hline 2002 & 18.1 & 17.0 & 14.6 & 16.7 & 12.6 & 11.4 & 16.7 & 18.4 & 23.3 & 14.9 & 11.8 & 14.0 \\
\hline 2003 & 20.9 & 22.2 & 19.4 & 24.0 & 25.7 & 28.5 & 22.3 & 24.5 & 20.4 & 23.5 & 27.7 & 27.8 \\
\hline 2004 & 11.7 & 14.3 & 18.6 & 17.7 & 22.0 & 26.3 & 13.1 & 15.4 & 41.6 & 21.9 & 28.7 & 41.5 \\
\hline 2005 & 3.8 & 3.7 & 8.0 & 3.9 & 6.4 & 8.1 & -3.0 & -3.8 & 2.1 & 6.9 & 8.5 & 12.1 \\
\hline 2006 & -3.1 & -3.8 & -3.2 & -2.1 & -2.0 & 1.0 & -3.5 & -2.5 & 0.3 & 1.3 & -0.2 & -1.1 \\
\hline
\end{tabular}




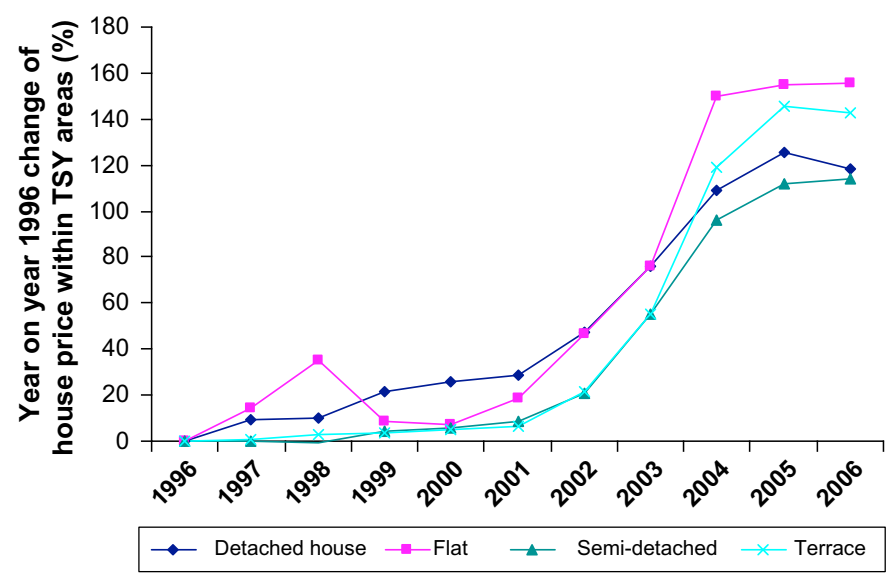

Fig. 4. Year-on-year 1996 price change (in \%) for all types of property in Transform South Yorkshire (TSY) pathfinder areas (price are adjusted with UK Consumer Price Index for housing).

such a price gap was denoted as a variable of $\Delta$ price. As mentioned in sub-section of 4.1, house prices in all these four local authority districts from 1996 to 2006 were below the region of Yorkshire and the Humber on average. Hence, $\Delta$ price is always in a positive value. Based on a pooled data set (i.e. 2000, 2001, 2002, 2005 and 2006), a general relationship in which competitiveness index score could be viewed as a linear function of price gap as follows,

$$
\text { IND }=-0.0004^{*} \text { Aprice }+93.641
$$

Where 93.641 is an intercept estimated from regression. IND denotes a competitiveness index and $\triangle$ price is the price gap. The total fitness of such a linear regression is measured by $R^{2} . R^{2}$ with a value over 0.91 , reflecting nearly $91 \%$ of cases can be explained by such a model, indicates a reliable and accepted regression as shown in Fig. 6. As shown in Fig. 6, it is observed that the competitiveness index increases significantly with a decrease of price gap, if the local house price is far below the regional average. If this were the case, restructure of housing market in TSY pathfinder areas to close the house price gap would lead to a significant increase of competitiveness of city region. According to Fig. 6, the marginal increase/decrease of competitiveness index would be 4 points, if the change of average local house price is 10,000 . Although such a quantitative examination simplifies the relationship between housing price and competitiveness of locality, this result can be directly transferred by social researchers to other cases where economic competitiveness needs to be forecasted based on housing marketing.

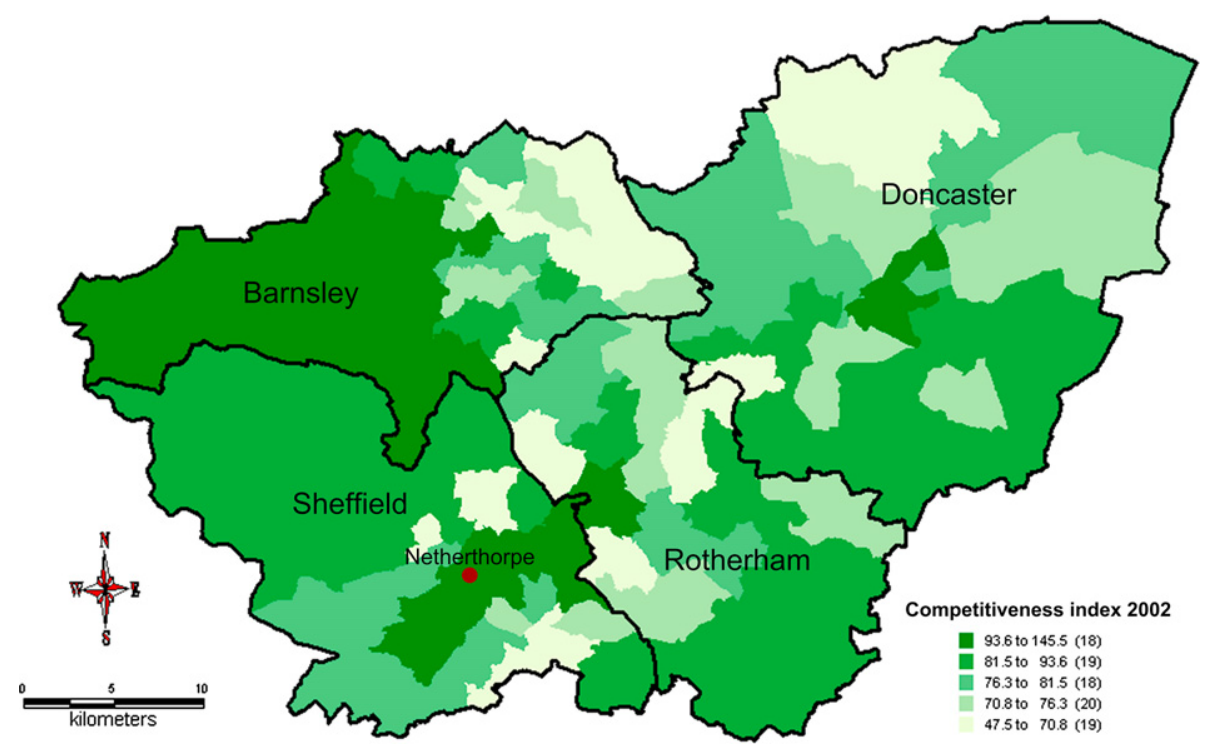

Fig. 5. Competitiveness index for wards in the South Yorkshire 2002. UK $=100$. The number of wards is in brackets. 


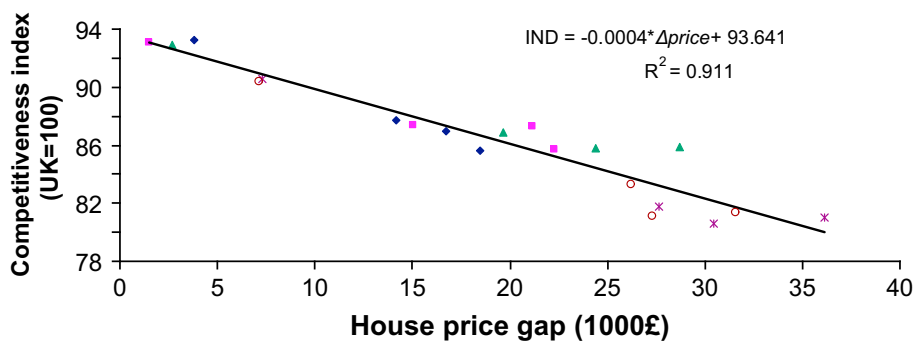

- Year 2000 - Year 2001 ^Year 2002 ○Year 2005 * Year 2006

Fig. 6. Relationship between competitiveness of local authority districts and housing price gap compared to the regional average. Black solid line indicates a general regression based on all pooled data from 2000, 2001, 2002, 2005 and 2006.

\section{Conclusions}

The research demonstrates the relative positive change/impact on house price. The housing market renewal program is making to re-model and improve many of the neighborhoods and settlements within the TSY pathfinder areas. Meanwhile, the research examines the relationship between the impact on house prices within the sub-region of South Yorkshire of the housing market renewal program, and its consequent effect on competitiveness of the city region by a spatial and statistical analysis. Key findings of the research include:

- the set out strategic axes covering seven priority local Transform South Yorkshire (TSY) Pathfinder areas are locations with greatest need for intervention and the strongest opportunities for positive change. This has potential to minimize spatial inequity of housing market development in the region of Yorkshire and the Humber;

- although gap of average house price between TSY, sub-region of SY and the region YH is increasing from 1996 to 2006 , the year-on-year change of average house price in TSY has a significant rise from 2004. Undoubtedly, such a progress symbolizes the start of reducing the gap between it and the sub-regional and regional average;

- compared with those of SY and YH, year-on-year change of price for all types of properties have a significant rise from 2003 or 2004 in TSY, indicating the TSY pathfinder is on course to improve housing quality;

- among all properties in TSY, markets for flats and terraced properties have been fully developed since 2003. As one of major themes of TSY is to increase access and housing option for residents. Over the next 10-year time frame by 2018, the detached and semi-detached properties would be targeted to provide good design, good quality.

- among the four local authority districts in South Yorkshire, housing market in Sheffield is the most fully developed, which is highly consistent with the result that Sheffield is the largest collection of wards within the top 20 competitive urban in the sub-region;

- a regression model was applied to briefly describe the linear relationship between price gap and city competitiveness, which can be directly transferred to other cases where economic competitiveness needs to be forecasted based on housing marketing.

\section{Acknowledgements}

The author gratefully acknowledges the advice and English syntax assistance of Lucy Mayblin from The University of Birmingham, UK. This work was supported by the National Natural Science Foundation of China (NSFC) with a grant number of 7080152, ShanDong Natural Science Foundation (\#2008BS09012), China and CAS innovation program numbered with AJ0911BX-099-3.

\section{References}

Annual Business Inquiry (2004). Available from https://www.nomisweb.co.uk/.

Chatterjee, S. (2003). On the contribution of agglomeration economies to the spatial concentration of US employment. Federal Reserve Bank of Philadephia. Mimeo.

Deas, I. (2001). Conceptualising and measuring urban competitiveness in major English cities: an exploratory approach. Environment and Planning A, 33, $1411-1429$

Dobkins, L., \& Ioannides, Y. (2001). Spatial interactions among US cities. Regional Science and Urban Economics, 31, $701-731$.

EKOS. (2006). South Yorkshire strategic economic assessment: Introduction and overview. UK: EKOS Consulting Limited. Report.

Glaeser, E. (2000). The future of urban research: non-market interactions. Brookings-Wharton Papers on Urban Affairs, 1, 101-150.

Glaeser, E., \& Gyourko, J. (2001). Urban decline and durable housing. Harvard University. Mimeo.

Glaeser, E., \& Scheinkman, J. (2003). Nonmarket interactions. In M. Dewatripoint, \& L. P. Hansen (Eds.), World congress, Vol. 1 (pp. 339-369). Cambridge: Cambridge University Press.

Green, F. (2003). The rise and decline of job insecurity. Working paper. Canterbury: University of Kent. 
Greenwood, J., \& Hercowitz, Z. (1991). The allocation of capital and time over the business cycle. Journal of Political Economy, 99, $1188-1214$.

Guezey, O. (2009). Urban regeneration and increased competitive power: Ankara in an era of globalization. Cities, 26, $27-37$.

Hall, T., \& Hubbard, P. (1998). The entrepreneurial city and the new urban politics. The entrepreneurial city. West Sussex, England: John Wiley and Sons. pp. 1-26.

Huggins, R. (2003). Creating a UK competitiveness index: regional and local benchmarking. Regional Studies, 37, 89-96.

Huggins, R., \& Day, J. (2006). UK competitiveness index 2006. Robert Huggins Associates. Report.

Ioannides, Y. (2003). Interactive property valuations. Journal of Urban Economics, 53, 145-170.

Ioannides, Y., \& Overman, H. (2003). Zipf's law for cities: an empirical examination. Regional Science and Urban Economics, 33, $127-137$.

Ioannides, Y., \& Zabel, J. (2003). Neighborhood effects and housing demand. Journal of Applied Economics, 18, 563-584.

Jones, C., \& Murie, A. S. (2006). The right to buy: Analysis and evaluation of a housing policy. Oxford: Blackwell, ISBN 1405131977.

Kresl, P. (1995). The determinants of urban competitiveness: a survey. In P. Kresl, \& G. Gappert (Eds.), North America cities and the global economy (pp. 45-68). Thousand Oaks, CA: Sage.

Lee, P., \& Ferrari, E. A. (2006). United Kingdom: changing spatial, ethnic and tenure patterns in England. In H. Beider (Ed.), Neighborhood renewal and housing markets: Community engagement in the US and UK. Blackwell.

Leung, C. (2004). Macroeconomics and housing: a review of the literature. Journal of Housing Economics, 13, 249-267.

Liu, X. \& Lee, P. Temporal-spatial analysis of regional house prices: do housing market renewal policies in the UK affect structural prices? In the Proceedings of the 7th China Urban Housing Conference, 2008.

Maliene, V., \& Malys, N. (2009). High-quality housing - a key issue in delivering sustainable communities. Building and Environment, 44, 426-430.

Mullins, D. W. (2006). Exploring change in the housing association sector in England using the Delphi Method. Housing Studies, $21,227-251$.

Murie, A. S., Hall, S. G., Rowlands, R. O., \& Sankey, S. (2005). RESTATE WKP8 large housing estates in the United Kingdom - Success and fail factors. European Commission.

National Statistics. (2009). Available from. http://www.statistics.gov.uk/cci/nugget.asp?id=181.

Ng, S. T., Skitmore, M., \& Wong, K. F. (2008). Using genetic algorithms and linear regression analysis for private housing demand forecast. Building and Environment, 43, 1171-1184.

Office for National Statistics. (2008). UK worth $£ 7$ trillion. Available from. http://www.statistics.gov.uk/cci/nugget.asp?id=479.

Parkinson, M., Simmie, J., Clark, G., \& Verdonk, H. (2004). Competitive European cities: where do the core cities stand? A Report to Office of the Deputy Prime Minister, London.

Pemberton, H. (2002). Policy networks and policy learning UK economic policy in the 1960s and 1970s. Public Administration, 78, 771-792.

Porter, M. (1990). The competitive advantage of nations. London: Macmillan.

Robert Huggins Associates. (2002). The state of urban Britain: UK competitiveness index 2002 city, metropolitan and ward benchmarking. Robert Huggins Associates.

Rogerson, R. J. (1999). Quality of life and city competitiveness. Urban Studies, 36, 969-985.

Rossi-Hansberg, E. \& Wright, M. Urban structure and growth. Paper presented at the 2004 SED meeting.

Scott, A. J., \& Storper, M. (2003). Regions, globalization, development. Regional Studies, 37, 579-593.

Shinm, Y., An, S. H., Cho, H. H., Kim, G. H., \& Kang, K. I. (2008). Application of information technology for mass customization in the housing construction industry in Korea. Automation in Construction, 17, 831-838.

Skinner, J. (1989). Housing wealth and aggregate saving. Regional Science and Urban Economics, 19, 305-324.

Soe, J. (2009). Balanced national development strategies: the construction of innovation cities in Korea. Land Use Policy, 26, 649-661.

Storper, M. (1996). Institutions of the learning economy. In B. A. Lundvall, \& D. Foray (Eds.), Employment and growth in the knowledge-based economy (pp. 255-286). Paris: Organisation for Economic Cooperation and Development.

Thurow, L. (1993). Head to head: The coming economic battle among Japan, Europe and America. London: Nicholas Breakey.

Transform South Yorkshire. (2005). Scheme framework update. Transform South Yorkshire. 